\title{
Scoring Systems Identifying the Low-Risk Febrile Neutropenia Patients in the Emergency Department: Usefulness of MASCC, CISNE and qSOFA
}

Acil Serviste Düşük Riskli Febril Nötropeni Hastalarını Tanımada Skorlama Sistemleri: MASCC, CISNE ve qSOFA Skorunun Kullanılabilirliği

ID Afsin Ipekci, ID Altug Kanbakan, (D) Yonca S. Akdeniz, ID Fatih Cakmak,
(ID) Serap Biberoglu, ID Seda Ozkan, (D) Ibrahim Ikizceli
Department of Emergency Medicine, Cerrahpasa Faculty of Medicine, Istanbul University Cerrahpasa, Istanbul, Turkey,

\begin{abstract}
Objective: We aimed to investigate the effectiveness of quick Sequential Organ Failure Assessment (qSOFA), Multinational Association for Supportive Care in Cancer (MASCC), and Clinical Index of Stable Febrile Neutropenia (CISNE) scores in identifying the low-risk febrile neutropenia (FN) patients among patients with chemotherapy-associated neutropenia in the emergency department setting.

Material and Method: The risk scores of the patients were calculated and divided into low-risk and high-risk categories according to the guidelines. Serious complications and 30-day mortality were recorded. Patients who survived and did not develop any serious complications were defined as low-risk FN.

Results: The median age of the patients was 63 years, and $56.3 \%$ were male. Of all patients, $50.6 \%$ had hematological malignancy. Blood culture positivity was detected in $31 \%$ of the patients. Of all patients, 51 (58.6\%) were low-risk FN. The complication rate in patients was $40.2 \%$, while the mortality rate was $25.3 \%$. When evaluated according to the risk scores, 69 (79.3\%) patients with qSOFA, 40 (46\%) patients with MASCC and 7 (8.1\%) patients with CISNE were classified as low-risk. The qSOFA score had the highest sensitivity with $96.08 \%$, MASCC had the highest PPV with $85 \%$, and the CISNE score had the highest specificity with $88.89 \%$ in patients with low-risk febrile neutropenia.

Conclusion: MASCC, CISNE and qSOFA scores have reasonable discriminating power in identifying low-risk neutropenia patients. The combined use of scoring systems with the clinical gestalt and communication with oncologists will further increase the percentage of the recognized low-risk neutropenic patients in the emergency department.
\end{abstract}

\section{ÖZET}

Amaç: Acil servis ortaminda qSOFA (quick Sequential Organ Failure Assessment), MASCC (Multinational Association for Supportive Care in Cancer) ve CISNE (Clinical Index of Stable Febrile Neutropenia) skorlarinin düşük riskli febril nötropeni ( $F N)$ hastalarının belirlemedeki etkinliğini ve kullanilabilirliğini araşstırmayı amaçladık.

Gereç ve Yöntem: Hastaların risk skorları hesaplanarak klavuzlara göre düşük riskli ve yüksek riskli kategorilerine ayrlld. Ciddi komplikasyonlar ve 30 günlük mortalite kaydedildi. Hayatta kalan veya ciddi komplikasyon gelişmeyen hastalar düşük riskli FN olarak tanımlandl.

Bulgular: Hastaların ortanca yaşl 63 yl olup, \%56,3'ü erkekti. Tüm hastaların \%50,6'sinda hematolojik malignite vardl. Hastaların \%31'inde kan kültürü pozitifliği saptandl. Tüm hastaların 51 'i $(\% 58,6)$ düşük riskli FN idi. Hastalarda komplikasyon oranı \%40,2 ve mortalite oranı ise \%25,3 idi. Risk skorlarına göre değerlendirildiğinde qSOFA skoruna, MASCC skoruna ve CISNE skoruna göre sirast ile 69 (\%79,3), 40 (\%46) ve $7(\% 8,1)$ hasta düşük riskli olarak sinıflandirlld. Düşük riskli febril nötropenili hastalarında qSOFA skoru $\% 96,08$ ile en yüksek duyarlillğa, MASCC \%85 ile en yüksek PPV'ye ve CISNE skoru \%88,89 ile en yüksek özgüllü̈̆e sahipti.

Sonuç: MASCC, CISNE ve qSOFA skorlarının düşük riskli nötropeni hastalarını belirlemede makul bir ayırt edici gücü vardır. Skorlama sistemlerinin klinik tecrübe ve onkologlarla iletişsim ile birlikte kullanılmasl, acil serviste düsük riskli nötropeni hastalarının tanınırlllı̆̆ının yüzdesini daha da artıracaktır.
Keywords: CISNE

Emergency department Febrile neutropenia $M A S C C$ qSOFA,

Anahtar Kelimeler: CISNE

Acil Servis

Febril nötropeni

$M A S C C$

qSOFA

\section{INTRODUCTION}

Febrile neutropenia (FN) is an important and lifethreatening oncological emergency that requires hospitalization and broad-spectrum antibiotic treatment (1). Infectious Diseases Society of America (IDSA) defined FN: Oral temperature measurement higher than $>38.3 \mathrm{C}^{\circ}$ in a single measurement or persistence at $>38^{\circ} \mathrm{C}$ for at least one hour. Absolute neutrophil count $<500$ cells/ microL, or anticipate this decrease within 48 hours (2). Its mortality is $5-11 \%$, and this rate increases up to $18 \%$ in the presence of bacteremia (3). However, not all patients with FN need to be hospitalized. The studies have shown that outpatient treatment of low-risk groups with broadspectrum oral antibiotics can be followed as it is both safe

Correspondence: Afşin İpekci, İstanbul Üniversitesi Cerrahpaşa Tıp Fakültesi Yerleşkesi, Kocamustafapaşa Cd. No: 53 Cerrahpaşa 34098 Fatih/İstanbul, Turkey. E-mail: afsin.ipekci@istanbul.edu.tr

Cite as: Ipekci A, Kanbakan A, Akdeniz YS, Cakmak F, Biberoglu S, Ozkan S, Ikizceli I. Scoring Systems Identifying the Low-Risk Febrile Neutropenia Patients in the Emergency Department: Usefulness of MASCC, CISNE and qSOFA. Phnx Med J. 2021;3(3):118-122.

Received: 07.09 .2021 Accepted: 27.09 .2021

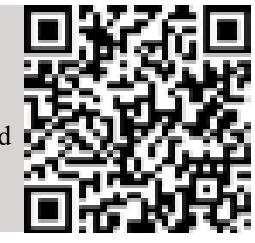




\section{Ipekci et al.}

and cost effective (4-7).

Accordingly, risk stratification methods for outpatient treatments have been developed. In 2000, the on-set of clinical instability, age, and comorbidity decided by Multinational Association for Supportive Care in Cancer (MASCC) was approved (8). In 2015, the Clinical Index of Stable Febrile Neutropenia (CISNE) score, which has been used in solid malignancies and is currently under evaluation in hematological malignancies, was developed. The CISNE score is based on clinical instability, laboratory data, and comorbid conditions (9). In addition, the Society of Critical Care Medicine (SCCM) and the European Society of Intensive Care Medicine (ESICM) 2016 described a simpler method called "quick SOFA (qSOFA)" for the prediction of early mortality in sepsis. qSOFA consisted of the following three elements: Respiratory rate $\geq 22 / \mathrm{min}$, Change in mental status, and Systolic blood pressure $\leq 100 \mathrm{mmHg}(10)$.

In our study, we aimed to investigate the effectiveness of qSOFA, MASCC and CISNE scores in identifying the low-risk FN patients among patients with chemotherapyassociated FN in the emergency department (ED) setting.

\section{MATERIAL AND METHOD}

\section{Study design}

This single-centered retrospective study was performed at the ED of university hospital which has 60,000 ED applications annually. Data were collected from hospital database between January 01, 2017, and January 01, 2020. The ethics committee approval was obtained (Date:

Table 1: Demographic characteristics of the patients

\begin{tabular}{lc}
\hline Age, median (min-max) & $63(28-79)$ \\
\hline Gender, n (\%) & $49(56.3)$ \\
Male & $38(43.7)$ \\
Female & \\
Tumor Type, n (\%) & $43(49.4)$ \\
Solid & $44(50.6)$ \\
Hematologic & $27(31)$ \\
Bacteremia, n (\%) & \\
Risk Classification and & \\
Categories, n (\%) & \\
qSOFA & $69(79.3)$ \\
Low-risk (0-1) & $18(20.7)$ \\
High-risk (2-3) & \\
MASCC & $40(46)$ \\
Low-risk $\geq 21$ & $47(54)$ \\
High-risk $<21$ & \\
CISNE & \\
Low-risk (0-1) & $69(70.3)$ \\
High-risk ( $\geq 2)$ & \\
Outcome, n (\%) & \\
Complication & \\
Mortality & \\
\hline qSOFA: quick Sequential Organ & Failure \\
Multinational Association for Supportive Care in Cancer, CISNE: \\
Clinical Index of Stable Febrile Neutropenia
\end{tabular}

February 14, 2020 and no: 26547).

Study protocol and selection of patients

Files of 102 patients with neutropenia were scanned. Fifteen patients were excluded from the study due to the absence of fever, diagnosis of acute leucosis, and unrelated chemotherapy. The IDSA criteria were used for diagnosis of chemotherapy-associated FN. Total of 87 patients who met criteria for FN were included in the study. Basic characteristics of the patients such as age, gender, type of malignancy, and outcomes were recorded.

The risk scores of the patients were calculated at the ED admission. The risk scores divided into low and high-risk categories according to the guidelines. Zero and 1 points were considered as low risk, and 2 and 3 points were considered as high risk for the qSOFA score. MASSC score $\geq 21$ points was consid-ered as low risk and score $<21$ was high risk. CISNE scores were divided into 3 categories: CISNE I was considered as low risk (0 points), CISNE II as medium risk (1-2 points), and CISNE III as high risk ( 3 points). In the calculations, CISNE score 0 and 1 was accepted as low risk and $\geq 2$ as high risk.

Patient who had one of any complications or died in 30 day of admission accepted as high-risk FN. Seri-ous complications were altered mental status, respiratory failure, organ failure, hypotension, arrhythmias that require intervention, and intensive care unit admission. Patients who survived or did not develop any serious complications were defined as low risk FN.

\section{Statistical analysis}

Statistical analysis was performed with the IBM SPSS statistics 21 software program for Windows (IBM Corp. Armonk, NY: USA. Released 2012). Frequency (n, \%), median, minimum-maximum (min-max) values, and Chisquare test were used in the analysis of the data. In lowrisk prediction analysis, standard sensitivity, specificity, positive predictive value (PPV), negative predictive value (NPV), positive likelihood ratio (LR+) and negative likelihood ratio (LR-) were calculated. In addition, qSOFA, MASCC and CISNE scores were measured with the area under the receiver operating characteristic curve (AUROC). P value $<0,05$ was accepted as statistically significant.

\section{RESULTS}

The median age of the patients was 63 years, and $56.3 \%$ were male. Of all patients, $50.6 \%$ had hematological malignancy. Blood culture positivity was detected in $31 \%$ of the patients. Of all patients, $51(58.6 \%)$ were low-risk FN. The complication rate in patients was $40.2 \%$, while the mortality rate was $25.3 \%$. When evaluated according to the risk scores, $69(79.3 \%)$ patients with qSOFA, 40 (46\%) patients with MASCC and 7 (8.1\%) patients with CISNE were classified as low risk (Table 1).

When the risk categories were compared in cases of complications and mortality, qSOFA and MASCC scores were found to be significantly different in both, while the CISNE score was found to be significantly different only in the case of complications (Table 2).

While the qSOFA score had the highest sensitivity with 96.08\% (86.54\%-99.52\%), MASCC had the highest PPV with $85 \%$ (72.69\%-92.35\%), and the CISNE score had the highest specificity with $88.89 \%$ (73.94\%-96.89\%) in 
Phnx Med J. November 2021, Volume 3 No 3

Table 2: Comparison of risk categories for complications and mortality.

\begin{tabular}{lccc}
\hline & None, $\mathbf{n}(\mathbf{\%})$ & Yes, $\mathbf{n}(\mathbf{\%})$ & p \\
\hline Complication & $52(58.8)$ & $35(40.2)$ & $<0.001$ \\
\hline qSOFA, low-risk $(0-1)$ & $50(96.2)$ & $19(54.3)$ & $<0.001$ \\
qSOFA, high-risk (2-3) & $2(3.8)$ & $16(45.7)$ & 0.030 \\
MASCC, low-risk ( $\geq 21)$ & $35(67.3)$ & $5(14.3)$ & \\
MASC, high-risk $<21$ & $17(32.7)$ & $30(85.7)$ & $<0.001$ \\
CISNE, low-risk $(0-1)$ & $15(28.8)$ & $3(8.6)$ & \\
CISNE, high-risk $(\geq 2)$ & $37(91.4)$ & $32(71.2)$ & 0.003 \\
\hline Mortality & $65(74.7)$ & $22(25.3)$ & $11(50)$ \\
\hline qSOFA, low-risk $(0-1)$ & $58(89.2)$ & $11(50)$ & 1 \\
qSOFA, high-risk $(2-3)$ & $7(10.8)$ & $4(18.2)$ & $18(81.8)$ \\
MASCC, low-risk $(\geq 21)$ & $36(55.4)$ & $4(18.2)$ & \\
MASCC, high-risk $(<21)$ & $29(44.6)$ & $18(81.8)$ & \\
CISNE, low-risk $(0-1)$ & $14(21.5)$ & $51(78.5)$ & \\
CISNE, high-risk $(\geq 2)$ & & \\
\hline
\end{tabular}

qSOFA: quick Sequential Organ Failure Assessment, MASCC: State Association for Supportive Care in Cancer, CISNE: Clinical Index of Stable Febrile Neutropenia

Table 3: Analysis of scoring systems in identifying low-risk febril neutropenia patients.

\begin{tabular}{lcccccc}
\hline & Sensitivity & Specificity & PPV & NPV & LR + & LR- \\
\hline qSOFA & $96.08(86.54-99.52)$ & $44.44(27.94-61.90)$ & $71.01(64.54-76.74)$ & $88.89(66.21-97.03)$ & $1.73(1.28-2.33)$ & $0.09(0.02-0.37)$ \\
MASCC & $66.67(52.08-79.24)$ & $83.33(67.19-93.63)$ & $85.00(72.69-92.35)$ & $63.83(53.82-72.76)$ & $4.00(1.88-8.52)$ & $0.40(0.26-0.61)$ \\
CISNE & $27.45(15 . .9-41.77)$ & $88.89(73.94-96.89)$ & $77.78(55.64-90.74)$ & $46.38(41.34-51.48)$ & $2.47(0.89-6.89)$ & $0.82(0.67-1.01)$ \\
\hline
\end{tabular}

qSOFA: quick Sequential Organ Failure Assessment, MASCC: Multinational Association for Supportive Care in Cancer, CISNE: Clinical Index of Stable Febrile Neutropenia, PPV: positive predictive value, NPV: negative predictive value, LR +: positive likelihood ratio, LR-: negative likelihood ratio

Table 4: AUROC values of risk scores in patients with low-risk febrile neutropenia.

\begin{tabular}{lccc}
\hline & AUROC & $\mathbf{9 5 \%}$ CI & p \\
\hline Complication & & & $<0.001$ \\
\hline qSOFA & 0.762 & $0.652-0.872$ & $<0.001$ \\
MASCC & 0.857 & $0.776-0.938$ & $<0.001$ \\
CISNE & 0.752 & $0.647-0.857$ & 0.006 \\
\hline Mortality & & & 0.001 \\
MSOFA & 0.695 & $0.553-0.837$ & 0.009
\end{tabular}

qSOFA: quick Sequential Organ Failure Assessment, MASCC: Multinational Association for Supportive Care in Cancer, CISNE: Clinical Index of Stable Febrile Neutropenia, AUROC: the area under the receiver operating characteristic curve, CI: confidence interval

patients with low risk FN (Table 3).

In general, MASCC score (AUC for complication 0.857, 95\% CI 0.776-0.938 and AUC for mortality $0.747,95 \%$ CI 0.634-0.859) had higher discriminable power for lowrisk patients than qSOFA and CISNE scores (Table 4).

\section{DISCUSSION}

Nowadays, the number of cancer patients requiring emergency room admissions due to complications are gradually increasing; they constitute $2-5 \%$ of emergency room admissions $(11,12)$. Since the patients' length of stay in the ED for hospitalization is increasing, early recognition and outpatient treatment for patients with
FN will be beneficial. In our study, although the qSOFA, MASCC and CISNE scores have different sensitivity, specificity, PPV and NPV values in identifying low-risk FN patients, have an overall reasonable discriminating power.

The qSOFA is a scoring system with a performance equivalent to Sequential Organ Failure Assessment (SOFA) score in predicting prognosis of patients with sepsis. In addition, the low number of criteria provides ease of use in the ED (13). Studies have shown that qSOFA helps in making a fast and accurate decision in predicting the poor prognosis of patients with FN (14). 


\section{Ipekci et al.}

In studies conducted with $\mathrm{FN}$ patients in intensive care, the AUC value was found to be 0.651 (95\% CI 0.513 0.789 ), which is lower than MASCC, and it was found to be an important predictor in terms of mortality and length of stay in intensive care $(15,16)$. However, to the best of our knowledge, there are no studies that identify low-risk FN patients with qSOFA. In our study, the sensitivity of qSOFA score in low-risk FN patients was $96.08 \%$, which was higher than that of others. However, its specificity was lower than that of others with $44.44 \%$ and indicating that it will be more beneficial to use it with others rather then using it alone.

The MASCC score was originally developed to identify low-risk patients and has been used for over 20 years. Studies have reported the sensitivity of MASCC score to be over $90 \%$ and specificity to be around $50-60 \%$. However, the AUROC of MASCC score was found high in the identification of low-risk FN $(8,15,17-20)$. In our study, although the sensitivity of qSOFA score and the specificity of CISNE score were higher than the MASCC score, the AUROC value of the MASCC score was the highest in identifying low-risk FN patients. The difference between sensitivity and specificity of the MASCC score is relatively lower than that of others, making this score valuable in identifying low-risk FN patients.

On the other hand, CISNE score was developed for the prediction of major complications in patients with solid tumors. The specificity of CISNE score was found over $90 \%$, and its sensitivity was found to be around $10-30 \%$ in studies performed to identify low-risk FN patients. In addition, the specificity for identifying low risk was found to be over $90 \%$ in patients with hematological malignancies (17-20). In our study in which hematological malignancies were equal, the high specificity of the CISNE score was $97.14 \%$ in identifying low-risk FN patients. This scoring system is valuable in emergency room conditions.

The limitations of our study included it being a singlecenter study, retrospective nature and small number of patients.

\section{CONCLUSION}

As a result, MASCC, CISNE and qSOFA scores have reasonable discriminating power in identifying low-risk FN patients. The combined use of scoring systems with the clinical gestalt and communication with oncologists will further increase the percentage of the recognized low-risk FN patients in the ED. In addition, we think that the increase in the percentage of patients to be treated in an outpatient setting with the correct diagnosis will be beneficial in preventing the ED crowd and decreasing unnecessary hospitalizations and complications that may develop during the waiting period.

Conflict Interest: The authors declare that there are no conflicts of interest.

Ethics: Clinical Research Ethics Committee of Cerrahpaşa Medıcal Faculty, Date: 16.01 .2020 an Number: 31887016$804.01-8830$

\section{REFERENCES}

1. Freifeld AG, Bow EJ, Sepkowitz KA, Boeckh MJ, Ito JI, Mullen CA, et al. Clinical practice guideline for the use of antimicrobial agents in neutropenic patients with cancer: 2010 update by the infectious diseases society of america. Clin Infect Dis. 2011;52(4):e56-e93.

2. Taplitz RA, Kennedy EB, Bow EJ, Crews J, Gleason C, Hawley DK, et al. Outpatient management of fever and neutropenia in adults treated for malignancy: American Society of Clinical Oncology and Infectious Diseases Society of America Clinical Practice Guideline Update. JCO. 2018;36(14):1443-1453.

3. de Naurois J, Novitzky-Basso I, Gill MJ, Marti FM, Cullen MH, Roila F. Management of febrile neutropenia: ESMO Clinical Practice Guidelines. Ann Oncol. 2010;21 Suppl 5:v252-v256.

4. Teuffel O, Ethier MC, Alibhai SMH, Beyene J, Sung L. Outpatient management of cancer patients with febrile neutropenia: a systematic review and meta-analysis. Ann Oncol. 2011;22(11):2358-2365.

5. Flowers CR, Karten C. Communicating safe outpatient management of fever and neutropenia. J Oncol Pract. 2013;9: 207-210.

6. Pherwani N, Ghayad JM, Holle LM, Karpiuk EL. Outpatient management of febrile neutropenia associated with cancer chemotherapy: risk stratification and treatment review. Am J Health Syst Pharm. 2015;72(8):619-631.

7. Freifeld A, Marchigiani D, Walsh T, Chanock S, Lewis L, Hiemenz J, et al. A double-blind comparison of empirical oral and intravenous antibiotic therapy for low-risk febrile patients with neutropenia during cancer chemotherapy. N Engl J Med. 1999;341(5):305-311.

8. Klastersky J, Paesmans M, Rubenstein EB, Boyer M, Elting L, Feld R, et al. The Multinational Association for Supportive Care in Cancer risk index: A multinational scoring system for identifying low-risk febrile neutropenic cancer patients. J Clin Oncol. 2000;18(16):3038-3051.

9. Carmona-Bayonas A, Jiménez-Fonseca P, Virizuela Echaburu J, Antonio M, Font C, Biosca M, et al. Prediction of serious complications in patients with seemingly stable febrile neutropenia: validation of the Clinical Index of Stable Febrile Neutropenia in a prospective cohort of patients from the FINITE study. J Clin Oncol. 2015;33(5):465-471.

10. Singer M, Deutschman CS, Seymour CW, Hari MS, Annane D, Bauer M et al. The third international consensus definitions for sepsis and septic shock (Sepsis-3). JAMA. 2016;315(8):801-810.

11. Can N, Yolcu Ş, Çetin Beceren NG, Tomruk Ö. Determination of Sociodemographic Characteristics of Cancer Patients Applying to Our Emergency Department and the Relationship Between Emergency Applications. Bozok Medical Journal. 2013;2:6-11.

12. Tokocin O, Cakmak F, Ipekci A, Tihan DN, Ceylan D, Sutasir MN, et al. Factors affecting the morbidity and mortality of malignancy patients admitted to the emergency department. Phnx Med J. 2019;1:8-14.

13. Liu Z, Meng Z, Li Y, Zhao J, Wu S, Gou S, et al. Prognostic accuracy of the serum lactate level, the SOFA score and the qSOFA score for mortality among adults with Sepsis. Scand J Trauma Resusc Emerg Med. 2019;27(1):51.

14. Lee SJ, Kim JH, Han SB, Paik JH, Durey A. Prognostic Factors Predicting Poor Outcome in Cancer Patients with Febrile Neutropenia in the Emergency Department: Usefulness of qSOFA. J Oncol. 2018;2018:2183179.

15. Kim M, Ahn S, Kim WY, Sohn CH, Seo DW, Lee YS, et al. Predictive performance of the quick Sequential Organ Failure Assessment score as a screening tool for sepsis, mortality, and intensive care unit admission in patients with febrile neutropenia. Support Care Cancer. 2017;25(5):15571562 .

16. Cetintepe T, Cetintepe L, Solmaz S, Calık S, Ugur MC, Gediz F, et al. Determination of the relationship between mortality and SOFA, qSOFA, MASCC scores in febrile neutropenic patients monitored in the intensive care unit. Support Care Cancer. 2021;29:4089-4094.

17. Ahn S, Rice TW, Yeung SJ, Cooksley T. Comparison of the MASCC and CISNE scores for identifying low-risk neutropenic fever patients: analysis of data from three emergency departments of cancer centers in three continents. Support Care Cancer. 2018;26(5):1465-1470. 
Phnx Med J. November 2021, Volume 3 No 3

18. Moon H, Choi YJ, Sim SH. Validation of the Clinical Index of Stable Febrile Neutropenia (CISNE) model in febrile neutropenia patients visiting the emergency department. Can it guide emergency physicians to a reasonable decision on outpatient vs. inpatient treatment?. PLoS One. 2018;13(12):e0210019.

19. Mohindra R, Mathew R, Yadav S, Aggarwal P. CISNE versus MASCC: Identifying low risk febrile neutropenic patients. Am J Emerg Med. 2020;38(11):2259-2263.

20. Coyne CJ, Le V, Brennan JJ, Castillo EM, Shatsky RA, Ferran K, Brodine S, et al Application of the MASCC and CISNE risk-stratification scores to 1dentify low-risk febrile neutropenic patients in the emergency department. Ann Emerg Med. 2017;69(6):755-764. 